\title{
Teologie van die koninkryk (Basileiologie)? Teologies nagedink oor die plek en betekenis van die koninkryk van God in die teologie en die kerk
}

\author{
Author: \\ Jan H. (Amie) van Wyk \\ Affiliation: \\ ${ }^{1}$ Unit for Reformational \\ Theology, North-West \\ University, Potchefstroom \\ Campus, Potchefstroom, \\ South Africa \\ Correspondence to: \\ J.H. van Wyk \\ Email: \\ amiejanvw@gmail.com \\ Postal address: \\ PO Box 11692, Silverlakes \\ 0054, South Africa \\ Dates: \\ Received: 20 Aug. 2014 \\ Accepted: 19 Jan. 2015 \\ Published: 31 Mar. 2015 \\ How to cite this article: \\ Van Wyk, J.H., 2015, \\ 'Teologie van die koninkryk \\ (Basileiologie)? Teologies \\ nagedink oor die plek en \\ betekenis van die koninkryk \\ van God in die teologie en \\ die kerk', In die Skriflig 49(2), \\ Art. \#1875, 12 pages. http:// \\ dx.doi.org/10.4102/ids. \\ v49i2.1875
}

\section{Copyright:}

(C) 2015. The Authors.

Licensee: AOSIS

OpenJournals. This work is licensed under the Creative Commons Attribution

License.

Read online:

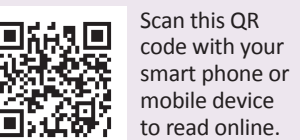

Hierdie artikel is 'n poging om aan te toon dat daar 'n groot leemte bestaan in die wyse waarop die klassieke leerstukke in dogmatiek in die verlede hanteer is, omdat dit 'n sentrale tema soos die koninkryk van God óf volkome geïgnoreer, óf totaal onderbelig het. Hierdie leemte word vervolgens nader ondersoek. Eers word aandag gegee aan die eskatologiese modelle wat in hierdie verband ontstaan het. Daarna word op die sentraliteit van die tema van die koninkryk in die Ou en Nuwe Testament gefokus en hierna word op die dinamiese uitwerking daarvan gelet wat dit op die samelewing behoort te hê. Die konklusie waartoe die outeur kom, is dat die tema van die koninkryk van God in die geheel gesien in die kerk en in die teologie totaal onderbeklemtoon was en steeds is. Vir 'n relevante kerkbeskouing (ekklesiologie) kan dit 'n groot bevryding bring indien die fokus van die kerk na die (gekome en komende) ryk van God verskuif. Die dogmatiek benodig 'n afsonderlike locus wat oor die Basileiologie handel.

Theology of the kingdom (Basileiology)? Theological reflections on the place and role of the kingdom of God in church and theology. This article is an attempt to demonstrate that there is a great void in the way in which classical doctrine was treated in dogmatics in the past, since it either completely ignored a central theme like the kingdom of God, or shed altogether insufficient light on it. This void will subsequently be investigated more closely. Firstly, attention is given to the eschatological models which came into being for it. Next, the focus is on the centrality of the theme of the kingdom in the Old and New Testament after which its dynamic effect on society is pointed out. The conclusion reached by the author is that the theme of the kingdom of God was and is on the whole underemphasised in the church and in theology. For a relevant view of the church (ecclesiology) it could be liberating if the church shifted its focus to the kingdom of God (that has come and is coming). Dogmatics needs a separate locus dealing with Basileiology.

\section{Inleiding}

\section{Is die koninkryk van God 'n sentrale teologiese tema?}

Bavinck (1922:51) merk op dat die koninkryk van God die wesenlike inhoud, die kern en doel van die ganse wêreldgeskiedenis uitmaak (vgl. Bright 1953:7; Van Ruler 1978:32), maar, sou 'n mens kon vra, waarom skryf hy in sy omvattende dogmatiek dan geen locus oor die koninkryk nie? Indien die hooftema van ál Jesus se preke oor die koninkryk van God gehandel het, waarom is dit nie vandag nog die hooftema van elke preek, elke gebed, elke liturgie en elke locus in die dogmatiek nie? ${ }^{1}$ Waarom bestee die kerk soveel aandag aan kerksake en so min aan koninkryksake? Waarom speel die tema van die koninkryk nie 'n dominante rol in die eskatologie nie? (Pannenberg 1993:527).

Steek daar dalk waarheid in die opmerking van Loisy dat Christus die koninkryk gepreek het en wat toe daaruit ontstaan het, die kerk is? (vgl. Van de Beek 2012:144; Van den Brink \& Van der Kooi 2013:530; Wentsel 2006:251).

Wanneer klassieke gereformeerde dogmatieke soos byvoorbeeld die Institusie van Calvyn (1984-1991; Inst. 2.10-11) of die Gereformeerde Dogmatiek van Bavinck (1929:174-213) nageslaan word, sal daarin geen locus oor die koninkryk van God gevind word nie.

1.Vergelyk Beker en Hasselaar (1981:182); Durand (2013:107); Grenz (1994:434-435); en Schlink (1985:298).

2.Calvyn (1984-1991) bestee in sy Institusie net een hoofstuk aan die eskatologie (Inst. 3.25) en dan handel dit hoofsaaklik oor die opstanding van die ligaam (vgl. verder Van der Kooi 1992:250-259; Van Wyk 2001a:191-205). 
Dieselfde geld van verskeie dogmatiese handboeke soos Beker en Hasselaar (1981; 1990), H. Berkhof (1990), ${ }^{3}$ L. Berkhof (1969:262-301; vgl. ook 1951), Grenz (1994), Heppe (1978:371-409), Heyns (1978:200-228), Migliore (1991), Ott (1981), Schleiermacher (1976), Schlink (1985), Spykman (1992), Van Genderen en Velema (1992:493-521) en Weber (1972) en - hoewel die tema van die koninkryk deur sommige navorsers wel as subtema behandel is. ${ }^{4}$ Dit is ' $n$ ope vraag waarom dit die geval is, gesien in die lig van die algemeen aanvaarde feit dat die koninkryk van God 'n sentrale plek in die prediking van Jesus Christus inneem (vgl. byvoorbeeld Deist \& Du Plessis 1985:98, 101; Küng 1967:55; Neill 1968:368; Ridderbos 1950:5, 33, 35, 39). Klein (1970:642-670) beskryf die koninkryk van God as 'n 'biblischer Zentralbegriff'.

Die argument dat die koninkryk die ganse teologie (en dogmatiek) beheers en dus nie 'n afsonderlike behandeling regverdig nie (vgl. Snyman 1977:198), gaan nie op nie aangesien so 'n sentrale tema juis buitengewone aandag regverdig.

\section{Ridderbos (1968) maak die volgende opmerking:}

Wat nu de traditie van de gereformeerde theologie betreft, men kan in het algemeen niet zeggen, dat het begrip van het Koninkrijk Gods daarin een centrale betekenis heeft ingenomen. In de gereformeerde confessies wordt van het Koninkrijk niet uitvoerig gesproken; ook neemt het in het totale structuur van deze belijdenissen niet een dominerende plaats in. (bl. 153; vgl. Dijkstra 1969:185-214) ${ }^{4}$

Moltmann (1997:43-45) wys daarop dat die reformatoriese teologie te veel aandag aan die temas van geloof en kerk bestee het en dat die onderwerpe van hoop en koninkryk daarin onderontwikkel is. Die eskatologie is te veel apokalipties vanuit die eindoordeel benader en te min Christologies vanuit die kruis en die opstanding van Christus - gebeurtenisse wat reeds vir die hede betekenis het. Dit is egter opvallend dat in een van die drie bekende ekumeniese simbole (in die Niceanum) eksplisiet na die koninkryk verwys word: cujus regni non erit finis [in aansluiting by die woorde van die engel aan Maria in Luk 1:33].

Na die periode van die Reformasie in die sestiende eeu volg die tydvak van die Aufklärung [agtiende eeu] waartydens die kategorie van hoop sodanig vernietig is dat Troeltsch by geleentheid opgemerk het dat die kantoor van die eskatologie in die negentiende eeu gesluit is (vgl. Bosch 1991:498-499; Sauter 1999:27). Die nuwe wat die Aufklärung wél gebring het, was die etiese verstaan van die koninkryk (vgl. Kant se geskrifte), bereikbaar deur menslike prestasie (Pannenberg 1993:34).

In die twintigste eeu is die temas van die koninkryk en die eskatologie herontdek en dit het die weg vir talle nuwe

3.Berkhof (1959:170-192) bring die tema van die (voleinding van die) koninkryk wel ter sprake in sy boek oor Christus as die sin van die geskiedenis.

4.Vergelyk hier die opmerking van Jonker (1994:89): "n Mens sou graag meer oor die koms van God se ewige koninkryk [by art. 37 NBG] wou gehoor het.' ondersoeke in hierdie verband gebaan (Williams 1997: 243-262) - ook ten opsigte van die etiek (vgl. Frey 1997:62-74; Ladd 1974:278-304; Merklein 1981; Phillips 2002:44-53). ${ }^{5}$

Eers word aandag gegee aan die eskatologiese modelle wat in hierdie verband ontstaan het. Daarna word gefokus op die sentraliteit van die tema van die koninkryk in die $\mathrm{Ou}$ en Nuwe Testament en hierna word gelet op die dinamiese uitwerking daarvan wat dit op die samelewing behoort te hê. Die konklusie is dat die tema van die koninkryk sentraal in kerk en teologie behoort te staan.

\section{Eskatologiese modelle in verband met die koninkryk van God ${ }^{6}$}

Wanneer die historiese ontwikkeling van die konsep van die koninkryk van God nagevors word, verskyn 'n veelheid standpunte en nuanses wat 'n lewendige beeld verskaf van hoe die teologie en die kerk oor hierdie konsep geoordeel het. Dit is verhelderend om die verskillende eskatologiese modelle nader uit te spel en kortliks toe te lig.

\section{Futuristiese (apokaliptiese) eskatologie}

Dit word redelik algemeen aanvaar dat die tema van die koninkryk van God in die Vroeë Kerk 'n sterk eskatologiesfuturistiese betekenis gehad het (Seeberg 1964, 1:74, 81; vgl. Van de Beek 2012:126). Die koninkryk van God sal met die tweede koms van Jesus begin (Seeberg 1964, 1:77). Dit beteken natuurlik nie dat invloedryke teoloë in hierdie periode nie oor die eskatologiese verwagting besin het nie (vgl. Chilton 1984; Frick 1928; Van der Walt 1969:151-184). Teenoor die Gnostisisme, wat die teenswoordigheid van die koninkryk benadruk het, het die teoloë van die tweede eeu die koninkryk hoofsaaklik eskatologies verstaan, dit wil sê toekomstig, hemels en ewig (Ferguson 1987:194, 199-200).

Hierdie model werk met 'n sterk toekomsgerigte (futuristiese) koninkryksverwagting. Die koms van die koninkryk, as 'n toekomstige werklikheid, moet eerder afgewag as aangehelp word. God alleen kan die koninkryk laat aanbreek en die koms daarvan lê verskuil in God se tyd en wyse. Die Christelike tradisie het (veral voor en na Heppe) in haar besinning op die eschata te veel klem op die na-tydelike lewe gelê, wat tot 'n spiritualistiese en vertikalistiese denke gelei het (Beker \& Hasselaar 1990:207).

5.Michealis (1987:116) wys op die opvallende feit dat die politieke of militêre metafoor, koninkryk, deur Jesus in terme van sagter beelde uitgelê word soos plant, groei, visvang, vroue wat brood breek, boere wat skatte vind en handelaars wat pêrels verkoop (en tien meisies wat vir 'n bruilof gereedmaak!).

6.Die oorspronklike artikel het hier 'n gedeelte bevat wat oor die 'historiese ontwikkeling van die konsep van die koninkryk van God' gehandel het. Dit is vanweë die lengte van die artikel verkort en by punt 2 ingewerk Vergelyk in vanwee die lengte van die artikel verkort en by punt 2 ingewerk. Vergelyk in hierdie verband die verskillende modelle wat deur Bosch (1991:502-504), Durand (2013:31-38), France (1993:303), Frey (1997:62-74), Heyns (1978:414-416) Moltmann (1996:6-29; 2012:9-41), Polman (s.a.:320-329), Preston (1993:304309), Ridderbos (1950:6-23), Runia (1997:105-135), Schwarz (2000:107-173), Van den Brink en Van der Kooi (2013:641-647), Van der Walt (1962:2-17), Van Genderen en Velema (1992:742-743), Welker (1992:497-512) en Wentsel (2006:675-682) behandel is. 
Hierdie (eensydige) futuristiese benadering van die koms van die Godsryk vind in die huidige teologiese debat weinig ondersteuning, aangesien die talle Nuwe-Testamentiese uitsprake oor die aanwesigheid van die koninkryk as 'n realiteit net te oorweldigend is. Die toekomskarakter van die koninkryk behou egter sy betekenis, omdat die voleinding, die volle en finale realisering daarvan met die wederkoms van Christus wanneer God alles vir alles sal wees (1 Kor 15:28), nog moet aanbreek.

\section{Gerealiseerde eskatologie}

Met die kerkvader Augustinus (354-430) tree 'n wending in ten opsigte van die eskatologie, omdat hy die koninkryk van God ook as 'n teenswoordige entiteit definieer (Seeberg 1964, 1:326). Augustinus lewer met sy boek, oor De civitate Dei (413-427), die eerste ontwerp van 'n teologie van die koninkryk (Augustinus 1983; vgl. Frick 1928:138-152). Vir hom vind die koninkryk van God nou reeds gestalte in die kerk: 'Die kerk is nou al die ryk van Christus en die ryk van die hemel' (civ. Dei 20.9). ${ }^{7}$ Die voleinding van die koninkryk behou egter sy toekomskarakter: die volk van God is 'n pelgrimsvolk op weg na die groot voleinding en die vernuwing van die hemel en die aarde.

Daar is egter teoloë wat hierdie model verder voer en beweer dat die koninkryk slegs (of hoofsaaklik) 'n gerealiseerde saak is. Die teoloog C.H. Dodd (1884-1973) word gewoonlik met hierdie model verbind: met die lewe, sterwe en opstanding van Jesus het die koninkryk van God gekom en is dit gerealiseer en hier teenwoordig (Dodd s.a.:7, 75). Ons mag hierby egter nie vergeet dat Dodd, naas die aanwesigheid van die koninkryk, ook die toekomstigheid (voleinding) daarvan aanvaar het nie (Dodd s.a.:27, 38, 41, 75, 108).

Veel groter klem as wat by Dodd ten opsigte van die gerealiseerde eskatologie te vind is, word by die Nederlandse teoloog Bram van de Beek aangetref. Volgens hom is die twintigste-eeuse koninkryksteologie te veel op die aardse mag gerig wat die koninkryk op aarde wil vestig (Van de Beek 2012:130-131):

De term 'Koninkrijk van God' om de komende heerschappij van God aan te kondigen is nu [na Pasen en hemelvaart] niet meer nodig, want het Koninkrijk is gekomen. Deze kan nu, als men wil, worden herijkt en de kerkvaders gebruiken de uitdrukking soms om het eeuwige leven aan te geven. (Van de Beek 2012:128)

Wie nu nog de term 'Koninkrijk van God' gebruikt zoals de evangeliën dat doen, miskent de komst van het Koninkrijk in

\footnotetext{
7.Hierdie tendens is ook in die Rooms-Katolieke teologie te vind (vgl. Ott 1981).Tydens die Middeleeue word die tema van die koninkryk van God geïnstitusionaliseer en grotendeels met die sigbare hiërargiese kerk geïdentifiseer (Braaten 1994:336). In Thomas Aquino se Summa Theologiae word die tema van die koninkryk byvoorbeeld nie breed uitgewerk nie - hoewel bygevoeg moet word dat Thomas se Summa nie verder as die Christologie gevorder het nie. In die dogmatiese konstitusie Lumen Gentium (1964; vgl. Neuner \& Dupuis 1983) van die Tweede Vatikaanse Konsilie word gestel dat die geheim van die koninkryk van God in die persoon en werk van Christus verkondig en gemanifesteer word en in die eindtyd gerealiseer sal word; die kerk verkondig en gemanifesteer word en in die eindtyd gerealiseer sal word; die kerk verkondig en ervaar dit as teenwoordige realiteit (Neuner \& Dupuis 1983:244). In 'n Katolieke Kategismus word gestel: 'Christ's kingdom already manifests its presence through the miraculous signs that attend its proclamation by the Church' (Catholi Church 1994:185). Hellwig (1991:358, 359) merk op: 'These official teachings up to the time of Vatican II dealt scarcely at all with general eschatology'; en: 'one would look in vain to Vatican II for an explicit account of a renewed understanding of eschatology' (vgl. Vaticaan Oecumenisch Concilie 1967).
}

Jezus, of beter: miskent dat Hij Koning is en alle macht in hemel en op aarde aan Hem gegeven is. Men miskent de eschatologische werklijkheid die de kerk is ...' (Van de Beek 2012:129; vgl. ook 1996 en 2005)

Daarom waarsku Van de Beek (2001:73-74) teen 'n koninkryksteologie wat te polities- en kultuuroptimisties gekleur is.

Die kritiese vrae wat in hierdie verband gestel word, is of daar volgens hierdie model reg aan die betekenis van die tussentyd tussen Pinkster en die parousie geskied (vgl. Van den Brink \& Van der Kooi 2013:646) en of dit nie te veel tot isolasie aanleiding gee nie (Van der Kooi 2012:379).

\section{Transendente eskatologie}

Daar is teoloë wat'n sterk aksent op die transendente aard van die koninkryk van God lê. Vir Johannes Weiss (1863-1914) moet die koninkryk as radikaal transendent, bo-aards en toekomstig gesien word, sonder enige aardse ontwikkeling (Willis 1987b:2). Die klem op die transendente aard van die koninkryk is ook by Karl Barth (1886-1968) aanwesig, maar hier vanuit die sentrale tema van die Christologie (kruis en opstanding) ontwikkel (Barth 1981:248-255; vgl. Moltmann 2012:19-24; Van der Kooi 2012:375-377). Barth ontken nie die immanente aspek van die koninkryk nie, maar hy rig sy verset teen die immanentisme wat die koms van die koninkryk van menslike aktiwiteite afhanklik maak (Barth 1981:244). Die vraag is egter of daar in die model van Barth voldoende ruimte vir die toekomstige aspek van die koninkryk is, aangesien God se heilsplan reeds volledig in Christus gerealiseer het.

Dit is natuurlik waar dat die Christen 'n 'vreemdeling en bywoner' op aarde is en op weg is na 'n 'beter vaderland' (Heb 11:13-15; vgl. 2 Kor 5:1-5; 1 Pet 1:4), maar hierdie vermelding impliseer nie wêreldontvlugting nie. Christene is nie van hierdie wêreld nie, maar nog steeds in hierdie wêreld. Christus bid nie dat sy navolgers uit die wêreld weggeneem word nie, maar dat hulle van die Bose bewaar sal word (Joh 17:15). Wanneer Christus aan Pilatus sê dat sy koninkryk 'nie van hierdie wêreld is nie', moet sy woorde in konteks verstaan word: sy koninkryk groei nie vanuit die sondige wêreld van geweld nie, maar is 'n geskenk van die Vader en daarom 'n ryk van vrede.

\section{Immanente eskatologie}

Hierdie benadering benadruk die aardse karakter van die koninkryk. Albrecht Ritschl (1822-1889) verstaan die koninkryk van God as persoonlike gemeenskap met God, wat met die oog op hierdie doel 'n ononderbroke ontwikkeling van menslike aktiwiteit na morele volmaaktheid aktiveer (Sauter 1999:27). Ritschl aanvaar dus 'n immanente koninkryk wat deur menslike morele deelname ontwikkel kan word (vgl. Willis 1987b:2). Nog 'n voorbeeld van hierdie model kan in die Social Gospel Movement van W. Rauschenbush (1861-1918) gevind word. 
Vir Rauschenbush is die koninkryk van God 'n sosiale werklikheid wat ekonomiese en politieke strukture transformeer. Hierdie model het tereg klem op die hiernoumaalse karakter van die koninkryk gelê, maar dit tot 'n gesekulariseerde koninkryk vereensydig. Dit was in hierdie verband dat Richard Niebuhr (1956:193) opgemerk het: 'A God without wrath brought men without sin into a Kingdom without judgement through the ministries of a Christ without a cross.'

\section{Spiritualistiese eskatologie}

Die spiritualistiese model gaan daarvan uit dat die koninkryk van God nie soseer in die kerk of die samelewing vorm aanneem nie, maar wel innerlik in die hart van die mens (vgl. Luk 17:21). Die koms van die Godsryk word as 'n innerlike en geestelike groeiproses gesien.

Origenes (185-254) oordeel byvoorbeeld dat die koninkryk op God (die Gees) se heerskappy in die hárt van die mens dui; die konsummasie bestaan nie in 'n abrupte inbreek van die koninkryk nie, maar in 'n innerlike groeiproses; hierdie internalisering van die koninkryk impliseer egter ook 'n individualisering daarvan (Ferguson 1987:198-199; Frick 1928:95-104).

Hierdie model is ook by Adolf von Harnack (1851-1930) te vind: die Godsryk is suiwer geestelik, bo-aards, ontkiem in die siel, behoort tot die gebied van die godsdiens en staan buite die gewone loop van dinge (Von Harnack 1903:46-48). So 'n ontaarde Godsryk het gevolglik weinig met samelewingsvraagstukke te doen. So 'n eensydige benadering vind egter weinig steun in die Ou- en NuweTestamentiese getuienis.

\section{Politisistiese eskatologie}

Teenoor die spiritualistiese benadering van die Godsryk, beklemtoon die bevrydings- en politieke teologie die sosio-ekonomiese relevansie van die Godsryk. Een van die bekendste name in hierdie verband is die teoloog Gustavo Gutiérrez (1974), maar vir die doeleindes van hierdie artikel word die aandag op twee Suider-Afrikaanse teoloë gevestig, naamlik Banana en Boesak. ${ }^{8}$

Teen die agtergrond van die Zimbabwiese vryheidstryd volg Banana 'n radikale benadering. Hy handhaaf naas ' $n$ immanente eskatologie (Banana 1991:53) ook 'n sterk gereduseerde eskatologie (1991:110) waarin die toekomsaspek byna verdwyn (1991:106). Hy kies duidelik vir 'n oorwegend sinergistiese benadering: 'The future lies in our hands, we are the makers of the kingdom of God' (1991:52); 'People are the makers of the kingdom of God through love, togetherness and sharing' (ibid:53); die koninkryk kom deur humaniteit, geregtigheid en gelykheid (Banana 1982:116). Die koninkryk moet hier en nou verwerklik word deur 'n sosialistiese rewolusie of transformasie (Banana 1991:10, 106; 1982:116). 'The only

8.'n Belangrike eksponent in hierdie verband is natuurlik ook Tutu (vgl. Allen 2006). possible answer and replica of the kingdom of God is socialism' (Banana 1982:132; vgl. ook Evans 1992:147-152; Ngara 2001).

Hierteenoor vind ons by die Suid-Afrikaanse teoloog Boesak 'n veel meer genuanseerder aanpak. Terwyl hy voluit in die tradisie van die (Suid-Afrikaanse) bevrydingsteologie staan, erken hy dat die koninkryk van God méér is as (selfs ' $n$ regverdige) politieke bedeling (Boesak 1979:16); ook 'n swart mag is nie in staat om die koninkryk van God te verwerklik nie (Boesak 1977:79). Waartoe die mens wél in staat is, is om tekens van die Godsryk op te rig (Boesak 1986:63; vgl. verder Boesak 2009; Van Wyk 2003a:385-401).

In hierdie verband geld dieselfde kritiese vrae wat ten opsigte van die immanente eskatologiese model gestel is. ${ }^{9}$

\section{Dualistiese eskatologie}

Voorbeelde van 'n dualistiese eskatologie, elk met sy eie nuanse, kan by Luther, die Anabaptisme en Stanley Hauerwas gevind word.

Luther (vgl. Moltmann 2012:9-13; Ruppert 1987) onderskei (soos Augustinus) tussen die koninkryk van God en die koninkryk van die duiwel asook tussen die (verlossende) koninkryk van Christus en die (onderhoudende) koninkryk van die wêreld. Teen die wyse waarop Luther hierdie twee ryke hanteer en uitgewerk het, is daar egter (soms skerp) kritiek ingebring, omdat hy die twee ryke nie net onderskei het nie, maar sodanig geskei het dat die effek van die Godsryk op die wêreldryk geminimaliseer is (vgl. Van Wyk 1991:216-220). Barth (1945:113) se kritiek was van die skerpste. Hy het aangevoer dat Luther se hantering van die twee-ryke-leer die groot oorsaak van die Duitse Christene se gebrek aan geestelike weerstand teen Hitler se nazisme was. Ook Bonhoeffer (1966:208-220) het kritiek teen die 'denke in twee ruimtes' uitgespreek.

'n Ander nuanse van hierdie dualistiese model is by die Anabaptisme van die sestiende eeu te vind. Wêreldmyding eerder as wêreldwyding was hulle benadering. Antitese tussen die sondige wêreldryk en die hemelse koninkryk was hulle siening (vgl. 'n uitgebreide Balke 1977; asook Moltmann 2012:27-30; Van Wyk 1991:224-227).

'n Moderne teoloog wat by hierdie dualistiese visie aansluiting vind, is Stanley Hauerwas. Hy hou die koninkryk van God en die koninkryk van die wêreld asook die kerk en die staat sover moontlik uitmekaar. Volgens hom moet die kerk nie 'n alternatief vir die huidige (Amerikaanse) politieke bestel soek nie, want die kerk ís 'n alternatiewe - en eskatologiese - gemeenskap (vgl. 'n uitgebreide Hauerwas 2002; Moltmann 2012:30-33; Van de Beek 2012:132-140).

Die kritiese vrae wat by hierdie dualistiese benadering gestel word, is indringend van aard. Hierdie model wys tereg

9.Vergelyk Noordmans (1980:115) se opmerking dat die koninkryk van God haastiger en sneller as 'n rewolusie is (vgl. ook 238, 313 asook 1986:628). 
die (fatale) identifikasie van die koninkryk van God met die koninkryk van die wêreld af, asook van die kerk met die staat. Dit ontken egter foutiewelik dat die (aanwesige!) Godsryk en die evangelie van Christus 'n kritiese, transformerende en genesende effek op die samelewing en die samelewingstrukture kan uitoefen.

\section{Holistiese eskatologie}

In die holistiese model gaan dit nie oor die hede óf die toekoms, die hemel óf die aarde, die hiernoumaals óf die hiernamaals, die individu óf die gemeenskap, die gees óf die liggaam nie, maar die Godsryk word as allesomvattende en alle-tye-omspannende heilswerk van God in Christus deur die Gees gesien. In hierdie verband kan veral aan die heilshistoriese eskatologie van Oscar Cullmann met sy veel gebruikte onderskeiding van D-dag en V-dag gedink word: met Paasfees is die beslissende slag (decisive battle) gelewer, maar die eindoorwinning kom nog op 'Victory Day'. Ons leef tans nog in die tussentyd waartydens die evangelie van die koninkryk en die koningskap van Christus wêreldwyd geproklameer moet word (Cullmann 1952:84).

Wat Nederland betref, kan veral aan die Nuwe-Testamentikus H.N. Ridderbos (1909-2007) gedink word soos hy dit in sy boek, De komst van het koninkrijk (1950), uitgewerk het. Dit bly steeds 'n belangrike klassieke werk. Die koninkryk van God het reeds met Paasfees en Pinkster gekom, maar nog nie voltooid in sy volle glorie nie. ${ }^{10}$ In die jongste gereformeerde dogmatiek van B. Wentsel (1991:534-611; 2006:184-276) ontvang die koninkryk ook afsonderlike en indringende aandag. ${ }^{11}$

Ook die Hervormde teoloog A.A. van Ruler (1908-1970) het die tema van die koninkryk op 'n besondere wyse benut - en ook 'n bepaalde invloed op Moltmann uitgeoefen. Vir Van Ruler is die koninkryk van God die sentrale gegewe 'van de gehele bijbelse verkondiging en leer' (Van Ruler 1978:32). Hy omskryf die koninkryk van God as 'het uiteindelijke en heilrijke handelen Gods met deze wereld' - met klem op die betekenis van elke woord in hierdie sin (Van Ruler 1947: 40-47). Geen wonder nie dat Van Ruler van mening is dat die ecclesia in diens moet staan van die basileia (Van Ruler 1971:98-100) - en nie omgekeerd nie (vgl. Van de Beek 2012:101-103). In Duitsland het veral Moltmann en Pannenberg besondere aandag aan die eskatologie en die koninkryk bestee.

In die teologie van J. Moltmann ${ }^{12}$ speel die eskatologie en die koninryk 'n sentrale rol (vgl. Bauckham 1999; Sauter 1999:132-138).Trouens, in sy beroemde boek oor die Theologie

10.So ook Durand $(2013: 46,106,109,125,128)$. Vergelyk in hierdie verband die oordrewe vorm van 'Christianisering van die samelewing' deur A. Kuyper (vgl. Van Wyk 1991:220-224).

11.Alhoewel die tema van die koninkryk nie geheel in die teologiese oeuvre van G.C. Berkouwer (1903-1996) ontbreek nie (vgl. Berkouwer 1963:237-272; 1970:244 1972:220; 1974:254-311), kan nie gesê word dat dit by Berkouwer'n sentrale plek inneem nie (vgl. Runia 1997:105-135; asook Van der Kooi 1992:270-275).

12. Moltmann $(2000: 89,90)$ erken die invloed wat Iwand, Weber en Van Ruler op sy belangstelling in die koninkryk van God gehad het. der Hoffnung beskou hy die ontdekking van die sentrale betekenis van die eskatologie vir die lewe en boodskap van Jesus as 'een van die belangrikste gebeurtenisse in die nuwere Protestantse teologie' (Moltmann 1969:26). Vir hom is die koninkryk van God die sentrale kernbegrip van die eskatologie (1969:191), wat oor die heerskappy en ryk van God handel (1969:195). Moltmann (1975:214-215) hou vas aan sowel die immanensie as die transendensie van die koninkryk, wat 'n ryk van vryheid is (Moltmann 1980:230, 239). Hy wys 'n transponering van die eskatologie na sowel die tyd (soos by Coccejus, Schweitzer \& Cullmann) as na die ewigheid (Barth, Althaus, Bultmann) af en ontwikkel 'n eskatologie van die komende God (Moltmann 1996: 6-29). Samevattend sê Moltmann (1997:46): 'Das Evangelium Christi ist das Evangelium vom Reich Gottes, denn Christus ist das Reich Gottes in Person.' Die Christendom staan of val vir Moltmann (1969:143; 2012:5) met die werklikheid van Jesus se opwekking uit die dood. Belangrike kenmerke van Moltmann se eskatologie is dus hoop, bevryding, ortopraksis en verwagting, met duidelike historiese en kosmiese kontoere.

In sy jongste boek beskryf Moltmann (2012:35-41) hierdie model ook as 'n transformerende eskatologie (en etiek). Die koninkryk van God is vir hom die sentrale begrip van die eskatologie en dit help hom om 'n etiek van hoop te ontwikkel wat die toekoms in die lig van die opstanding van Christus sien (Moltmann 2012:41).

In W. Pannenberg se rasionele teologie speel die eskatologie en die koninkryk 'n belangrike rol (vgl. Sauter 1999:126-132). Ook hy is van mening dat ' $n$ koninkryksentriese benadering in die teologie onmisbaar is (Pannenberg 1991:146, 164, 224, 309-310, 326-334). Die ontdekking van die betekenis van die eskatologie vir die hele Christelike belydenis, kenmerk die twintigste-eeuse teologie (Pannenberg 1993:532). Omdat God en sy heerskappy die sentrale inhoud van die eskatologiese verlossing uitmaak, kan die eskatologie nie bloot 'n onderwerp van 'n enkele hoofstuk in die dogmatiek uitmaak nie, 'want dit bepaal die perspektief van die Christelike dogma in sy geheel' (1993:531). Die eskatologie omvat die vervolmaking van die individuele lewe en die konsummasie van die mensheid en die wêreld in die koninkryk van God (1993:546). Die basis van die eskatologie is die gemeenskap met Jesus Christus, wat méér is as 'n belofte, omdat dit op die opstandingsgebeure van Christus, wat reeds plaasgevind het, rus (1993:540). Hierdie gebeure moet egter met die werk van die Heilige Gees gekomplementeer word (1993:551) pneumatologie en eskatologie hang immers saam (1993:552). Die koninkryk van God kan ook as die voltooiing van die menslike samelewing gesien word: die Christelike eskatologie verwag die versoening van die individu en die gemeenskap in die koninkryk van God (1993:585). 'n Immanentistiese eskatologie is daarom onvoldoende. Pannenberg (1993:595) beskou die verhouding tussen tyd en ewigheid as 'die kernprobleem' in die eskatologie. Die toekoms van die voleinding is vir hom die intrede van die ewigheid in die tyd (1993:603). 
Wat Suid-Afrika betref, was dit veral die Potchefstroomse teoloë van die GKSA wat die tema van die koninkryk van God as die sentrale teologiese tema ontgin het. Hiervan is die publikasie van Die koninkryk van God in 1969, 'n getuienis (vgl. Du Toit et al. 1969). Die Ou-Testamentikus, S. du Toit (1905-1982), het in aansluiting by John Bright, en die NuweTestamentikus W.J. Snyman (1899-1982) in aansluiting by Herman Ridderbos, die koninkryk as hooftema ontwikkel (Du Toit 1969; Snyman 1977). Die opvallende in Snyman (1977:195-224) se benadering is dat hy die uitstorting van die Heilige Gees as die snypunt hanteer en daarom die volgende driedeling gebruik: die koms van die koninkryk vóór Pinkster (Johannes die Doper en Christus), die koms van die koninkryk mét Pinkster (die uitstorting van die Heilige Gees) en die koms van die koninkryk ná Pinkster. Du Toit en Snyman het in J.L. Helberg (1980) en L. Floor (1974; $1981)^{13}$ belangrike navolgers gevind. Veral Floor se boek, Die koninkryk van God en die vernuwing van die maatskappy, moet as baanbrekerswerk vir sy tyd aangemerk word. Hierin wys hy enersyds op die gevare wat die koninkryk bedreig (sekularisering, spiritualisering, nasionalisering, internalisering (Floor 1974:9-19), maar aan die ander kant ook op die relevansie van die koninkryk vir die samelewing (1974:58-78).

In die teologietradisie van die Nederduitse Gereformeerde Kerk (NGK) ${ }^{15}$ het veral J.A. Heyns (1928-1994) die onderwerp van die koninkryk van God uitgewerk (vgl. Heyns 1967) sterk in aansluiting by en onder invloed van die Potchefstroomse teoloë (Heyns 1994a:163, 179; vir 'n bespreking hiervan, vgl. Van Wyk 2001b:222-225, met bronverwysings, asook Theron 1978). Dit is egter verbasend dat, terwyl Heyns die tema van die koninkryk eksplisiet in sy etiek behandel het (Heyns 1986:38-67), hy in sy dogmatiek (1978) daarvoor geen locus ingeruim het nie (vgl. ook Heyns 1994b:455-471). ${ }^{16,17}$

Dit is egter opvallend dat die teologie van die NGK oor die algemeen nie veel méér koninkryk-georiënteerd is nie, indien in aanmerking geneem word dat in die vroegste periode (1858-1919) die dogmatiek van Van Oosterzee, wat een van die weinige dogmatieke is wat die tema van die koninkryk uitdruklik benut het, as handboek aan die Kweekskool op

13.Die proefskrif van T. van der Walt, Die koninkryk van God - naby! (1962), verdien besondere vermelding in hierdie verband.

14.In die etiek het Van Wyk met sy Etiek en eksistensie - in koninkryksperspektief (2001b) 'n bydrae probeer maak.

15.Vergelyk hier die (latere) opmerking van De Villiers (2008:380): 'Die motief van Koninkryk van God en die oortuiging dat die kerk in diens staan van dié Koninkryk moet weer sentraal staan in die teologie van die NG Kerk.' Vergelyk ook König (1970; 1988; 2014).

16.Sommige teoloë in die NGK, byvoorbeeld Olivier (1997:111), het egter hulle kommer daaroor uitgespreek dat ' $n$ koninkryk-van-God-teologie in die sewentigeren tagtigerjare in die NGK hoogty gevier het en dat dit veels te triomfalisties en te weinig maatskappy-krities ingestel was - waarskynlik'n sinspeling op J.A. Heyns by wie die tema van die koninkryk van God 'n sentrale rol gespeel het. Ook van die kant van die feministiese teologie word die motief van koninkryk ('n koning wat héérs) krities bevraagteken.

17.Dit val op dat al hoe meer Christelike filosowe die tema van die koninkryk van God ook in die filosofie begin benut, sodat naas 'n Filosofie van die Openbaringsidee (Bavinck), en 'n Filosofie van die Wetsidee (Vollenhoven \& Dooyeweerd) en ' $n$ Filosofie van die Skeppingsidee (Stoker), ook'n Filosofie van die Koninkryk begin vorm aanneem (vgl. Botha 1971:161-165; Wolters 1992:39-41, 60, 64-72).
Stellenbosch gebruik is ${ }^{18}$ (Brümmer 2013:128-140; Deist 1994:8). Van Oosterzee is na 1919 deur die dogmatiek van Bavinck vervang. ${ }^{19}$

Samevattend kan na die studie van Van Bruggen (1983:158 e.v.) in verband met die koninkryk van God verwys word. Vanuit 'n theologia crucis kies hy teen 'n kontinue, optimistiese en ewolusionistiese denkmodel, en vanuit 'n theologia resurrectionis teen 'n diskontinue, pessimistiese en apokaliptiese model. In die eerste geval is sprake van futurum sonder eschaton, in die tweede van eschaton sonder futurum. Kragtens die verbondsgedagte bepleit hy 'n koöperatiewe model waar God die mens as bondgenoot in diens van die koms van sy koninkryk gebruik. Hoewel hy die gedagte van 'bou aan' die koninkryk afwys (Van Bruggen 1983:67, 169), handhaaf hy op grond van Kolossense 4:11 die gedagte dat ons medewerkers vir (met die oog op, in die rigting van) die koninkryk kan wees. Maar hierdie medewerking kan slegs deur lyding geskied, deur die navolging van die Gekruisigde (Van Bruggen 1983:167-171).

Inderdaad gaan dit in die Nuwe Testament eerstens daaroor om in die koninkryk 'in te gaan' en nie om in die kerk 'opgeneem te word' nie - hoe ongeskeie die verhouding tussen die kerk en koninkryk ook al omskryf mag word (vgl. Matt 5:20; 7:21; 18:3; 19:23-24; Joh 3:5). Intrede in die koninkryk geskied uit genade, maar dit is geen goedkoop genade nie. Intrede vra om metanoia, om totale denk- en daadverandering, om ' $\mathrm{n}$ nuwe lewe in navolging van Christus en vernuwing deur die Gees van God.

\section{Die sentraliteit van die koninkryk van God in die Skrif}

Dit is op hierdie stadium nodig om die vraag te probeer beantwoord of die tema van die koninkryk van God inderdaad 'n sentrale tema in die Skrif is en of die Basileiologie 'n aparte locus in die dogmatiek regverdig.

Wat die Ou Testament betref, word algemeen aanvaar dat die term koninkryk selde daarin voorkom (vgl. malkoet in Von Rad 1965:565-571) maar veral tydens die intertestamentêre periode na vore gekom het. Tog is die sáák self, naamlik die Here God se omvattende en genadige heerskappy, oral in die Ou Testament aanwesig (vgl. S. du Toit in Toit et al 1969: 11-13; Durand 2013:55-85; Palmer 1986:17-34).

Die Ou-Testamentiese eskatologie moet verstaan word in noue verband met God se skeppingswerk en sy heilsplan met Israel (vgl. Ps 46:11; 47:1-5; 48:5-11; 97:1; 103:19; 145:13;

18.Van Oosterzee (1876) behandel die Godsleer onder die volgende temas 'Opperkoning van die Godsryk', die antropologie onder 'onderdaan van die Godsryk', die Christologie onder 'Jesus Christus stigter van die Godsryk', die soteriologie onder 'heil en heilsweg van die Godsryk', die ekklesiologie onder 'kerk as kweekskool van die Godsryk' en die eskatologie as 'toekoms en voltooiing van die Godsryk'.

19.So ver my kennis strek, het Hervormde teoloë in Suid-Afrika nie uitgebreide aandag aan die tema van die koninkryk van God gegee nie en dit is ook nie as sentrale tema uitgewerk nie. Vergelyk byvoorbeeld die studies van Engelbrecht (1978), D.J.C. Van Wyk (1999) en Beukes (2003). Vergelyk egter ook die studie van Nel en Van Aarde (2002:1113-1133) 
1 Kron 29:11, 13; Dan 2:44; 4:3; 6:27). Die ganse boodskap van die Ou Testament spreek van God se koningskap, heerskappy en heilsplan, selfs wanneer sy oordele oor Israel en die nasies voltrek word. Die gebeure rondom Abraham, Moses, die eksodus, Sinai, die intog in die Beloofde Land, die Rigters, die konings, die profete, die ballingskap, die terugkeer, die tempel, die Godstad Jerusalem, alles lewer 'n lewendige illustrasie van die koningskap van die God van Israel en die Skepper van die heelal (vgl. Matt 25:34). Die OuTestamentiese eskatologie dui uiteindelik op 'n koninkryk wat universeel, regverdig, vredevol en eties verantwoord sal wees (Palmer 1986:30-31). Die Ou Testament eindig met 'n oop deur na die toekoms, met 'n onvervulde verwagting na 'n nuwe heilbrenger (Jes 9 en 11) en 'n nuwe hemel en 'n nuwe aarde (Jes 65).

In die boodskap van die Nuwe Testament kom die tema van die koninkryk van God in die woorde en dade van die Messias, Jesus, duidelik aan die lig en dit vorm die sentrale tema van die ganse Nuwe Testament (Durand 2013:104-119; Van den Brink \& Van der Kooi 2013:314; Weber 1972:745). Die basileia tou Theou dui veral op drie sake, naamlik eerstens dat God regeer, tweedens waaroor Hy regeer (oor alles) en derdens hoe Hy regeer (heilvol) (vgl. Schmidt 1965:576-593; verder Ridderbos 1950, Van der Walt 1962). ${ }^{20}$

Weber (1972:745) maak tereg die volgende opmerking: 'Das Reich Gottes steht in der Mitte aller christlichen Erwartung, und es umschliesst alles, was im einzelnen zu ihr gesagt werden muss.' Van den Brink en Van der Kooi (2013) kom tot dieselfde konklusie:

De komst van dat Koninkrijk, een leven waarin God regeert en alle mense de knie voor Hem buigen, vormt de grote heilshistorische accolade die alle thema's van de christelijke leer met elkaar verbindt. (bl. 313)

En: 'De centrale plaats die het Koninkrijk van God als vervulling van de profetische verwachting inneemt in de prediking en het optreden van Jezus is in de klassieke dogmatiek vaak onderbelicht gebleven', 'n leemte wat eers met die studie van Ridderbos oor hierdie onderwerp gevul is (Van den Brink \& Van der Kooi 2013:429).

Wanneer die Nuwe-Testamentiese boodskap noukeurig nagegaan word, is dit gou duidelik dat die tema van die koninkryk van God daarin 'n sentrale rol speel (vgl. slegs Syman \& Floor in Du Toit et al. 1969:34-58; Durand 2013: 104-142; Palmer 1986:37-63; Wentsel 2006:184-186).

Wanneer Johannes die Doper begin preek, roep hy almal op tot bekering, want die koninkryk van God het naby gekom (Matt 3:2). Wanneer Jesus sy openbare optrede begin, is sy boodskap dieselfde: bekeer julle en glo die evangelie, want die koninkryk het naby gekom (Mark 1:15). Sy ganse optrede staan in die teken van die koms van die heilryke Godsryk.

20.Schlink (1985:389) onderskei tussen Christusheerskappy en Godsheerskappy oo die wêreld - sonder om die twee te skei. Palmer (1986:18) onderskei in die Ou Testament tussen God se algemene heerskappy oor die wêreld en sy besondere heerskappy oor Israel.
Met die koms van die Koning, Jesus, is die koninkryk van hiér, by die mense (Luk 17:21). Al sy preke, redes en gelykenisse het net een tema en dit is die koninkryk van God (Durand 2013:107). Selfs gedurende sy laaste 40 dae op aarde ná sy opstanding, het Hy net een onderwerp gepredik en dit was die koninkryk van God (Hand 1:3). Sy wonderwerke dra dieselfde boodskap oor. Sy kruisdood en opstanding uit die dood vorm die kulminasiepunt van sy koninklike - en tegelyk priesterlike - optrede. Jesus se opwekking uit die dood word uitgebeeld as die geheim van die koninkryk van God (Durand 2013:121; vgl. Joh 12:31; 16:33; 1 Kor 15:24-26; Heb 2:14). ${ }^{21}$ Die koninkryk van God word as die kosbaarste besitting (pêrel) op aarde (Matt 13:45-46) beskryf - ja, iets wat bó alles en vóór alles en ín alles gesoek moet word (Matt 6:33).

Die evangeliste, Paulus, die skrywers van die algemene sendbriewe en Openbaring, vertel almal, elkeen met sy eie nuanses, die verhaal van die koms van die koninkryk van God in sy aanvang, voortgang en voleinding. Oënskynlik lyk dit asof dit vir Paulus meer oor die kerk van Christus as oor die koninkryk van God gaan, maar dit is 'n oppervlakkige waarneming. In belangrike passasies van sy evangelieboodskap verwys Paulus uitdruklik na die koninkryk as die omvattende tema (vgl. Rom 14:17; 1 Kor 4:20; 6:9, 10; 15:24, 50; Gal 5:21; Ef 5:5; Kol 1:13; 4:11; 1 Tess 2:12; 2 Tess 1:5; vgl. ook 2 Tim 4:1, 18).22 Lukas vertel byvoorbeeld dat Paulus vir twee maande in die sinagoge in Efese met die Jode oor die koninkryk van God geredeneer het (Hand 19:8; vgl. ook 14:22). Hy meld ook dat Paulus tydens sy gevangenskap in Rome vir twee jaar mense ontvang het en die koninkryk van God aan hulle verkondig het (Hand 28:31). Daarom is dit volkome begryplik dat Paulus aan die ouderlinge van Efese die vervulling van sy lewenstaak kan omskryf as die verkondiging van 'die evangelie van God se genade', wat op sy beurt weer niks anders is nie as die verkondiging van 'die koninkryk van God' (Hand 20:24-25).

Daar is een aspek wat ten opsigte van die koms van die koninkryk van God nog beklemtoon moet word en dit is die betekenis van die persoon en werk van die Heilige Gees. Hierdie feit tree al duidelik aan die lig tydens Christus se openbare optrede wanneer Hy 'n duiwelbesetene genees en daarby opmerk: 'Aangesien Ek deur die Gees van God die duiwels uitdryf, het die koninkryk van God inderdaad tot by julle gekom' (Matt 12:28). Tereg is opgemerk dat die uitstorting van die Heilige Gees met Pinkster 'n 'beslissende plek' in die koms van die koninkryk van God inneem (Snyman \& Floor aangehaal in Du Toit et al. 1969:49). Dit is die Heilige Gees wat mense inspireer om die oerbelydenis van die Vroeë Kerk na te spreek, naamlik 'Jesus is die Here' (Rom 10:9; 1 Kor 12:3; 2 Kor 4:5; Fil 2:11). Dit is die Heilige Gees wat die geskiedenis in die rigting van die koninkryk van God aandryf (Van den Brink \& Van der Kooi 2013:449).

21. Wanneer die Nuwe-Testamentiese betekenis van die kuis en opstanding van Jesus geloën word en Jesus bloot as voorbeeldige mens gesien word, soos by Abel Pienaar (2014), verval die eskatologiese betekenis van sy werk daarmee.

22.Vergelyk hier Noordmans (1979:434) se opmerking dat die tema van die koninkryk van God sentraal in Romeine is. 
Die eskatologie word eers reg verstaan wanneer dit in Christologiese en Pneumatologiese perspektief gesien word. Dit is uit die Nuwe Testament duidelik dat die NuweTestamentiese eskatologie dié van die Ou Testament vervul en sodoende met die belofte van 'n nuwe (hernude) hemel en aarde eindig waar geregtigheid woon en waar die wil van God heers (2 Pet 3:13; Op 21:1) en waar God alles vir almal is (1 Kor 15:28). ${ }^{23}$

\section{Die dinamika van die koninkryk van God}

Die vraag wat homself op hierdie stadium na vore dring, handel oor die werking en dinamika van die koninkryk van God op aarde. Wat is die implikasies daarvan dat die hemelse koninkryk op áárde gekom het, onder, by en in die mense? Die volgende sewe aspekte verdien hierby aandag.

Die eerste aspek is dat die koninkryk van God (die kerk) produseer. Die Godsryk produseer die kerk as dienende, verloste en versoende geloofsgemeenskap op aarde. Indien Loisy bedoel het dat Christus die koninkryk van God verkondig het en dat die kerk toe in die plek daarvan ontstaan het, is dit 'n misvatting; indien hy egter bedoel het dat die koms van die koninkryk die kerk geproduseer het, is dit 'n juiste siening. Die kerk is immers die geloofsgemeenskap waar die koningsheerskappy van Jesus as Here openlik aanvaar en bely word en so vorm die kerk 'n sigbare gestalte van die Godsryk op aarde. Die kerk is ook die gemeenskap waarbinne die Gees van God en van Christus lewend teenwoordig en werksaam is. Dit waarop Israel lank gewag en gehoop het en waaroor die profete so veel geprofeteer het, naamlik 'n nuwe koninkryk van vrede en heil, het met die koms van Jesus Christus en die Heilige Gees, 'n realiteit geword - maar nou 'n ryk wat uit alle volke en tale en nasies bestaan.

Diekerkas koninkryksvolkkannatuurlik ook as verbondsvolk beskryf word. Die verbond kan dan as innerlike gestalte van die koninkryk en die koninkryk as uiterlike gestalte van die verbond beskou word (Van Wyk 2003b:19). Die koninkryk vereis (veral) gehoorsaamheid en die verbond dui veral op gemeenskap.

Omdat die koninkryk die kerk produseer, beteken dit ook dat die kerk die Godsryk op aarde introduseer. Aan die kerk is immers die opdrag gegee om die evangelie van die

\footnotetext{
23.Daar heers onder NG-teoloë'n meningsverskil oor die verstaan van die 'nuwe heme en die nuwe aarde'. Volgens Heyns (1978:412-414; 1992:410) en König (2001:383) word hierdie ou aarde vernuwe; daar is dus kontinuïteit en diskontinuilteit (Barnard 2005:345, 347; vgl. Joubert 2012:653). Conradie (2006:220) twyfel egter of hiérdie aarde vernuut gaan word - ' $n$ standpunt wat deur die Lutherse Ortodoksie oorgeneem is. Ook Tolmie dink in hierdie rigting, naamlik dat die 'huidige wêreld" met Jesus se koms sal 'ophou om te bestaan'; 'hierdie wêreld verdwyn en dit word vervang deur 'n nuwe wêreld' (vgl. Van der Watt \& Tolmie 2014:371, 391-394). Durand (2007:581) wys ook op kontinuïteit en diskontinuïteit, maar gee voorkeur aan die gedagte van vervanging van die eerste skepping (Durand 2007:585,588). Hoewel die Nuwe Testament die nuwe óf as 'n transformasie van die oue, ó as 'n Hoewel die Nuwe Testament die nuwe of as " $n$ transformasie van die oue, of as " totale nuwe skepping beskou (Durand 2013:556), sê 2 Petrus 3:13 en Openbaring 21:1 dat die nuwe die oue 'verplaas en vervang' (Durand 2013:357, 359). Die fokus val veral op die hemel (Durand 2013:360-369). By König (2014:94, 421) verdwyn die 'nuwe hemel' as skeppingsrealiteit en word die eindbestemming van gelowige slegs die 'nuwe aarde', want dit word dan 'hemel op aarde'. Die Skrif verwys egte deurgaans na 'n nuwe hemel en 'n nuwe aarde (2 Pet 3:13; Op 21:1) - dit wil sê 'n nuwe heelal.
}

koninkryk aan alle nasies te verkondig (Matt 24:14; 28:18-20; Mark 16:15; Hand 1:6-8). Wanneer mense die evangelie van die koninkryk aanvaar, wanneer hulle hulle gehoorsaam en gewillig onder die koningsheerskappy van Christus en sy Gees stel, wanneer hulle 'n totale lewensomkeer maak (1 Kor 6:9-10), gaan hulle 'n nuwe lewe binne en leef hulle binne die ligkring van God se nuwe ryk (Kol 1:12; 1 Tess 5:5; 1 Pet 2:9) wat 'n ryk van vrede, vreugde en geregtigheid is (Rom 14:15).

Die tweede aspek is dat die koninkryk van God (in die kerk) manifesteer. Tot dusver is aangevoer dat daar 'n noue relasie tussen die koninkryk en die kerk bestaan en dat hulle onderskei maar nie geskei behoort te word nie. In die kerk, as volk van God, liggaam van Christus en tempel van die Heilige Gees, vind 'n (voorlopige en onvolkome) manifestasie van die koninkryk plaas - hoewel die koninkryk wyer as die kerk strek.

Die kerk is 'n voorlopige gestalte van die koninkryk, want die voleinding van die koninkryk moet nog eenmaal met die wederkoms van Christus aanbreek; met die vernuwing van die hemel en die aarde en die volheid van God in alles. Daarby is die kerk ook 'n onvolkome gestalte van die Godsryk, omdat daar nog soveel ongehoorsaamheid, onwilligheid en sonde in die kerk aangetref word. 'n Duidelike voorbeeld van hierdie ongehoorsaamheid is in die tragiese wyse te vind waarop die een kerk van Christus in duisende denominasies verdeel het wat mekaar opponeer en dikwels weerspreek. Watter getuienis kan 'n verdeelde kerk, wat 'n baken van versoening in 'n onversoende wêreld moet wees, aan die wêreld lewer? Loop 'n verdeelde koninkryk nie die gevaar om ten gronde te gaan nie (Matt 12:25)?

Die Godsryk manifesteer en neem 'n voorlopige gestalte aan in die kerk. Kan dieselfde ook van 'n Christelike skool en 'n Christelike universiteit gesê word? Sien ons ook iets van die realisering van die Godsryk in Christelike organisasies? In hierdie verband kan geargumenteer word dat ons in die kerk van Christus, met sy besondere kenmerke van evangelieverkondiging en sakramentsbediening, 'n besondere gestalte van die koninkryk aantref, maar dat in die Christelike organisasies wel tekens van die Godsryk aanwesig is, omdat die koningsheerskappy van Christus ook daar erken en bely word.

Die derde aspek is dat die koninkryk (alle aardse ryke) relativeer. Hierdie waarheid het Christus aan sy disspels geleer, naamlik dat die Godsryk groter, belangriker en standhoudender is as die aardse ryk van Israel waarop sy dissipels so bly hoop het (Hand 1:6-8). 'Jesus is die Here', het Paulus in sy tyd aan die Hellenistiese en Romeinse Christene geleer, waar die keiser as god en here (kurios) vereer is. Hierdie tema het die kerkvader Augustinus in die vyfde eeu in sy boek, De civitate Dei, diepsinnig uitgewerk in 'n tyd toe die sogenaamde onverganklike Romeinse Ryk in 410 begin verkrummel het: aardse ryke (en stede) is verganklik, net die ryk van God (die Godstad) bly vir ewig staan. 
Alle aardse ryke is relatief, broos, verganklik en verbygaande van aard: die Egiptiese, Assiriese, Babiloniese, MediesPersiese, Griekse, Romeinse, Europese, Amerikaanse, Chinese, ook die Suid-Afrikaanse. Wie aan 'n aardse ryk absolute gesag toeken, of dit vereer en vergoddelik, pleeg afgodery. Slegs die een ware God en sy Christus moet vereer word. Net die Godsryk is onverganklik.

Hier moet egter iets bygevoeg word, hoewel dit nog nie in die tyd van die Nuwe Testament voorgekom het nie, naamlik dat die koms van die Godsryk ook elke vorm van kerkisme en kerkabsolutisme relativeer. Hierbo is daarna verwys dat die een kerk van Christus in duisende dikwelse opponerende denominasies uiteengeskeur word. Daarom is dit belangrik dat elke kerkformasie steeds daaraan herinner sal word dat die Godsryk belangriker is as die kerk en dat die legitimiteit van elke kerk aan haar diensbaarheid aan die koninkryk van God gemeet word. Juis hierdie kriterium behoort kerkgroepe te oortuig om groter erns met die saak van kerklike eenheid en ekumenisiteit te maak (vgl. Van Wyk 2010:51-67).

Die vierde aspek is dat die koninkryk van God (Christene en die Christelike kerk) aktiveer. Dit is uit die Skrifgetuienis duidelik dat die kerk as geloofsgemeenskap 'n houding van eskatologiese verwagting inneem ten opsigte van die voltooiing van die Godsryk. Die vraag is of die kerk ook die koms van die koninkryk kan beïnvloed en selfs verhaas? Hier kan gedink word aan die uitspraak in 2 Petrus 3:12 waar vermeld word dat Christene hulle vir die koms van die dag van God moet 'beywer' (NAV). Die OAV vertaal dit meer korrek met 'verhaas'.

Die wagtyd op en die verwagtyd vir die eskatologiese vervulling is dus ook werktyd met die oog op die vervulling daarvan (vgl. Matt 24:46) en die aanbreek van 'n nuwe hemel en 'n nuwe aarde vol geregtigheid. 'n Mens sou dus ook kon sê dat oral waar Christene en die kerk hulle vir die saak van geregtigheid in die samelewing beywer, iets van God se nuwe wêreld sigbaar word (vgl. Matt 5:6). In hierdie verband moet twee gevare vermy word (Bosch 1991:506), te wete 'the sin of temerity', waar die mens in vermetelheid sy eie werk oorskat enersyds, en 'the sin of timidy', waar die mens in beskroomdheid vir minder hoop as wat belowe is andersyds. Die fanatikus en aktivis dink dat die koms van die koninkryk van hulle werk afhanklik is, terwyl die fatalis en passivis meen dat hulle niks vir die koms daarvan hoef te doen nie.

Die vyfde aspek is dat die koninkryk van God (die samelewing) penetreer. In hierdie verband is daar veral twee metafore wat hierdie aspek duidelik illustreer, naamlik die van sout en suurdeeg. Christus tipeer die burgers van die koninkryk as 'sout vir die aarde' (Matt 5:13). Sout kan alleen sy preserverende en smaakgewende funksies vervul indien dit die voedsel penetreer. Hiermee word uitgebeeld dat Christene nie soos olie op die water dryf nie, maar 'n samelewing diepgaande binnedring en ten goede beïnvloed. Dieselfde gedagte kom na vore in die beeld van die suurdeeg: 'Die koninkryk van die hemel is soos suurdeeg wat 'n vrou gevat en in 'n groot skottel meel ingewerk het totdat dit heeltemal deursuur was' (Matt 13:33). Onsigbaar soos sout, oefen suurdeeg sy deurdringende werking uit totdat die meel heeltemal (holon) deursuur is. Die Godsryk is dus nie ' $n$ effeklose en invloedlose entiteit nie, maar dit het ' $n$ diepgaande en indringende invloed op die samelewing. Dit groei soos 'n nietige mosterdsaadjie en omspan uiteindelik die ganse kosmos (Matt 13:31-32).

Die sesde aspek is dat die koninkryk van God ('n samelewing) transformeer. Hierbo is aangevoer dat die koninkryk 'n penetrerende effek in die samelewing het. Indien die eienskappe van die koninkryk as vrede, vreugde en geregtigheid omskryf kan word (Rom 14:17), kan dit nie anders nie as dat dit 'n transformerende en renoverende effek op 'n samelewing moet uitoefen, veral waar die kerk van Christus ' $n$ beduidende deel van die samelewing uitmaak en sy priesterlike, profetiese en koninklike taak op legitieme wyse vervul. Veral Moltmann (2012:35-41) het op hierdie aspek gewys en selfs die ekologiese vraagstuk (2012:131-145) en menseregte (2012:217-228) hierby betrek. Ook Wentsel (2006:212) het hierop gewys deur te noem dat Christene na optimale gunstige stoflike en sosiale omstandighede vir randfigure en behoeftiges in die samelewing moet strewe (vgl. Floor 1981:81-100; Hansen et al. 2011, dele 5 \& 6; en uitgebreid Smit 2007).

Die kerkstryd in Suid-Afrika tydens die apartheidsjare (1948-1994) ten gunste van 'n vrye en regverdige samelewing, kan in hierdie verband as ' $n$ duidelike illustrasie dien. Ook in hierdie verband geld egter dat die koms van die koninkryk uiteindelik nie van menslike aktiwiteite afhanklik is nie - die fout wat sommige bevrydingsbewegings gemaak het - maar van God self. ${ }^{24}$ Reg benader, kan 'n Christelike opvoedkundige sentrum ook'n klein teken wees van die komende Godsryk.

Die sewende aspek is dat die koninkryk van God (die burgers van die Godsryk) motiveer. Die eskatologiese verwagting op die voleinding, op die nuwe hemel en die nuwe aarde, word deur die motief van hoop lewend gehou. Hoop hou die wêreld gaande. Paulus skryf: 'As ons hoop op wat ons nie sien nie, wag ons (gretig) daarop met volharding' (Rom 8:25).

Die angswekkende gebeurtenisse wat ons planeet aarde in die verlede getref het en steeds tref soos oorloë, hongersnode, aardbewings, oorstromings, tsoenami's, omgewingsbesoedeling en aardverwarming, is nie tekens van die einde nie, maar van die voleinding; nie doodsnikke nie, maar geboortepyne en die begin van 'n nuwe tyd (Matt 24:8). Wat aan die verbygaan is, is nie die wêreld nie, maar die (sondige) gedaante van die wêreld (1 Kor 7:31). ${ }^{25}$

24.Die sogenaamde "kultuurmandaat" (Gen 1:28) kan alleen sinvol verstaan word wanneer dit binne die konteks van die eskatologiese verwagting van die koninkryk van God benader word (Van Wyk 2001b:481-482).

25.Ook Origenes (2009) het nie die vernietiging van die huidige aarde voorgestaan nie, maar die 'verandering van eienskappe' (1.6.4). Dit gaan vir hom uiteindelik oor die 'volledige herstel van die hele skepping' (3.5.7). Origenes se gedagte dat 'n oor die 'volledige herstel van die hele skepping' (3.5.7). Origenes se gedagte dat ' $n$
(alwerksame) God talle agtereenvolgende wêrelde skep, is egter baie spekulatief $(1.4 .5 ; 3.5 .3)$. 
Die verwagting van en hoop op die koms van God se voltooide ryk, sy nuwe hemel en nuwe aarde, motiveer elke Christen en die Christelike kerk om diensvaardig te arbei en hoopvol te evangeliseer. Die Godsryk het gekom en is in aantog in sy volheid. Christene is nie pessimiste of optimiste nie, maar spesimiste, hoopvolle mense op pad na die voleinding (Van Wyk 2012:65). ${ }^{26}$

\section{Uitleiding: Basileiologie? Inderdaad!}

Uit die bogenoemde argumentering word dit duidelik dat die tema van die koninkryk van God - as Basileiologie ongetwyfeld 'n aparte locus in die dogmatiek regverdig, en wel net na die Pneumatologie en voor die Ekklesiologie. Die behandeling van die koninkryk hoort logies tuis ná die Christologie (die persoon en werk van Christus) en die Pneumatologie (die persoon en werk van die Heilige Gees (vgl. Matt 12:28) en voordat met die leer oor die kerk (Ekklesiologie) begin word. Omdat die koninkryk so 'n sentrale rol in die prediking van Christus gespeel het, kan selfs aangevoer word dat dit in 'n sekere sin elke locus van die Christelike leer beïnvloed en bepaal. Bavinck het tereg opgemerk dat die koninkryk die wesenlike inhoud, kern en doel van die ganse wêreldgeskiedenis uitmaak.

Die verwagting van die voleinding van die koninkryk maak van die teologie 'n teologie van hoop. Die kerk wag op, werk vir en hoop op die Groot Toekoms wat God belowe het. ${ }^{27}$ Daarom mag die bede wat Christus ons geleer het, naamlik 'Laat u koninkryk kom!' (Matt 6:10), nooit verstil nie.

Die bede om die koms van die koninkryk is ' $n$ gebed dat die Godsryk in al sy volheid sal aanbreek, 'n gebed om die verskyning van die nuwe hemel en die nuwe aarde waar alles goed en reg sal wees, sonder sonde, sonder dood en sonder bose magte - en God alles vir alles.

\section{Erkenning}

Hierdie artikel word in dankbare erkentlikheid aan 'n vriend en kollega, Jan du Rand, opgedra met groot waardering vir sy ontsluiting van die boodskap van die Nuwe-Testamentiese en veral Johannese geskrifte. Die artikel sluit aan by en bou voort op 'n vorige artikel van my wat gehandel het oor 'verbond en koninkryk' (Van Wyk 2003b).

\section{Mededingende belange}

Die outeur verklaar dat hy geen finansiële of persoonlike verbintenis het met enige party wat hom nadelig of voordelig kon beïnvloed het in die skryf van hierdie artikel nie.

\section{Durand (2013) sluit in sy voorwoord hierby aan.}

27.Verskeie outeurs wys tereg daarop dat die Skrif nie uitdrukkings gebruik soos dat Christene moet 'bou aan' die Godsryk, of dit moet 'help oprig' nie (Küng 1967:59;
Snijders 1991:153; Van Bruggen 1983:167, 169; Van de Beek 1996:205-211), maar Snijders 1991:153; Van Bruggen 1983:167, 169; Van de Beek 1996:205-2
dit impliseer nie dat hulle blote passiewe toeskouers moet wees nie.

\section{Literatuurverwysings ${ }^{28}$}

Allen, J., 2006, Rabble-rouser for peace: The authorized biography of Desmond Tutu, The Free Press, London.

Augustinus, A. 1983, Aurelius Augustinus: De stad van God, vert. G. Wijdeveld, Ambo, Baarn. (Afgekort as civ. Dei).

Balke, W., 1977, Calvijn en de Doperse radikalen, Ton Bolland, Amsterdam.

Banana, C.S., 1982, Theology of promise: The dynamics of self-reliance, The College Press, Harare.

Banana, C.S., 1991, Come and share: An introduction to Christian theology, Mambo, Gweru.

Barnard, A., 2005, Ons troos: Jesus kom weer! Fokus op meer as 100 vrae oor die Eindtyd, Lux Verbi, Wellington.

Barth, K., 1945, Eine Schweitzer Stimme 1938-1945, Evangelischer Verlag, Zürich.

Barth, K., 1981, The Christian life: Church dogmatics, vol. 4, Lecture fragments, transl. G.W. Bromiley, Clark, Edinburgh.

Bauckham, R. (ed.), 1999, God will be all in all: The eschatology of Jürgen Moltmann Clark, Edinburgh.

Bavinck, H., 1922, Kennis en leven, Kok, Kampen.

Bavinck, H., 1929, Gereformeerde Dogmatiek, deel 3, Kok, Kampen.

Beker, E.J. \& Hasselaar, J.M., 1981, Wegen en kruispunten in de dogmatiek, deel 3 , Kok, Kampen.

Beker, E.J. \& Hasselaar, J.M., 1990, Wegen en kruispunten in de dogmatiek, deel 5 , Kok, Kampen.

Berkhof, H., 1959, Christus de zin der geschiedenis, Callenbach, Nijkerk.

Berkhof, H., 1990, Christelijk geloof: Een inleiding tot de geloofsleer, 2e dr., Callenbach, Nijkerk.

Berkhof, L., 1951, The kingdom of God: The development of the idea of the kingdom, especially since the eighteenth century, Eerdmans, Grand Rapids.

Berkhof, L., 1969, Systematic theolog, 2nd edn., Eerdmans, Grand Rapids.

Berkouwer, G.C., 1963, De wederkomst van Christus, deel 2, Kok, Kampen.

Berkouwer, G.C., 1970, De kerk, deel 1, Kok, Kampen.

Berkouwer, G.C., 1972, De kerk, deel 2, Kok, Kampen.

Berkouwer, G.C., 1974, Een halve eeuw theologie: Motieven en stromingen van 1920 tot heden, Kok, Kampen.

Beukes, J.C., 2003, 'Kultuurkritiek en die Hervormde benadering tot teologiebeoefening: 'n Gestaltegewing en uitdaging', Hervormde Teologiese Studies 59(1), 31-46. http://dx.doi.org/10.4102/hts.v59i1.651

Boesak, A., 1977, Farewell to innocence: A social-ethical study of Black Theology and Black Power, Raven, Johannesburg.

Boesak, A., 1979, Die vinger van God: Preke oor geloof en politiek, Raven, Johannesburg. Boesak, A., 1986, Als dit verraad is ben ik schuldig, Ten Have, Baarn.

Boesak, A., 2009, Running with horses: Reflections of an accidental politician, Joho, Cape Town.

Bosch, D.J., 1991, Transforming mission: Paradigm shifts in the theology of mission, Orbis, Maryknoll.

Botha, M.E., 1971, Sosio-kulturele metavrae, Buijten \& Schipperheijn, Amsterdam.

Bonhoeffer, D., 1966, Ethik, E. Bethge (ed.), Kaiser, München.

Braaten, C.E., 1994, 'The kingdom of God and life everlasting', in P.C. Hodgson \& R.H. King (eds.), Christian theology: An introduction to its traditions and tasks, pp. 328-352, Fortress, Minneapolis.

Bright, J., 1953, The kingdom of God: The biblical concept and its meaning for the church, Abingdon, New York.

Brümmer, V., 2013, Vroom of regsinnig? Teologie in die NG Kerk, Bybel Media, Wellington.

Calvyn, J., 1984-1991, Institusie van die Christelike godsdiens 1559 (1-), vert. H.W. Simpson, Calvijn Jubeleumboekefonds (CJBF), Potchefstroom.

Catholic Church, 1994, The Catechism of the Catholic Church, Gweru, Mambo.

Chilton, B. (ed.), 1984, The kingdom of God, Fortress, Philadelphia. (Issues in Religion and Theology 5).

Conradie, E., 2006, Waar op dees aarde vind mens God? Op soek na 'n aardse spiritualiteit, Lux Verbi.BM, Wellington.

28.Ten tye van die afronding van hierdie artikel was die volgende boeke nie in biblioteke in Suid-Afrika beskikbaar nie:

Hell, L., 1993, Reich Gottes als Systemidee der Theologie: Historisch-systematische Untersuchungen zum theologischen Werk, Grünewald, Mainz.

Hong, C.C., 1961, A history of the future: A study of four major eschatologies, University Press, Washington.

Neuhaus, R.J., 1969, Theology and the kingdom of God, Westminster, Philadelphia. Van't Spijker, W. et al. (red.), Eschatologie: Handboek over de Christelijke toekomstverwachting, Kok, Kampen.

Venema, C.P., 2001, The promise of the future, Banner of Truth, Edinburgh. 
Cullmann, O., 1952, Christ and time: The primitive Christian conception of time and history, transl. F.V. Filson, SCM, London.

Deist, F., 1994, Ervaring, rede en metode in Skrifuitleg: 'n Wetenskapshistoriese ondersoek na Skrifuitleg in die Ned. Geref. Kerk 1840-1990, Raad vir Geestewetenskaplike Navorsing (RGN), Pretoria.

Deist, F. \& Du Plessis, I., 1985, God en sy ryk, Van Schaik, Pretoria.

De Villiers, D.E., 2008, 'Kan die NG Kerk nog 'n konstruktiewe rol in die SuidAfrikaanse samelewing speel?', Verbum et Ecclesia 29(2), 368-386. http://dx.doi. org/10.4102/ve.v29i2.20

Dijkstra, H., 1969, 'Die koninkryk van God in die konfessies' in S. du Toit (red.) et al, Die koninkryk van God, bl. 185-214, Potchefstroom Herald, Potchefstroom.

Dodd, C.H., s.a., De apostolische prediking en haar ontwikkelingsgang: Drie lezingen met een bijvoegsel over 'Eschatologie en geschiedenis', vert. H.C. Dirkse-Bresters, Callenbach, Nijkerk.

Du Toit, S., 1969, Openbaringsgeskiedenis van die Ou Testament, Pro Rege Pers, Potchefstroom.

Du Toit, S. et al. (reds.), 1969, Die koninkryk van God, Potchefstroom Herald, Potchefstroom.

Durand, J., 2007, Die A-Z van Openbaring: 'n Allesomvattende perspektief op die boek Openbaring, Christelike Uitgewersmaatskappy, Vereeniging.

Durand, J., 2013, Die einde: Die A-Z van die bybelse boodskap oor die eindtyd, Christlike Uitgewersmaatskappy, Vereeniging.

Engelbrecht, B., 1978, Teologie in die kerk, HAUM, Pretoria.

Evans, J.H. (Jr.), 1992, We have been believers: An African-American Systematic Theology, Fortress, Minneapolis.

Ferguson, E., 1987, 'The kingdom of God in early patristic literature', in W. Willis (ed.) The kingdom of God in 20th-century interpretation, pp. 191-208, Henddrickson, Peabody.

Floor, L., 1974, Die koninkryk van God en die vernuwing van die maatskappy, Pro Rege Pers, Potchefstroom

Floor, L., 1981, Die evangelie van die koninkryk: 5 Aspekte, NG Kerkboekhandel, Pretoria.

France, R.T., 1993, 'Kingdom of God: New Testament', in A.E. McGrath (ed.), The Blackwell Encyclopedia of Modern Christian Thought, pp. 301-304, Blackwell, Oxford.

Frey, C., 1997, 'Eschatology and ethics: Their relation in recent continental Protestantism', in H.G. Reventlow (ed.), Eschatology in the Bible and in Jewish and Christian tradition, pp. 62-74, Sheffield Academic Press, Sheffield.

Frick, R., 1928, Die Geschichte des Reich-Gottes-Gedankens in der alten Kirche bis zu Origines und Augustin, Verlag von Alfred Töpelmann, Giessen.

Grenz, S.J., 1994, Theology for the community of God, Broadman \& Holman, Nashville.

Gutiérrez, G., 1974, Theologie van bevrijding, vert. R.M.K. Van der Grijp, Ten Have, Baarn.

Hansen, L., Koopman, N. \& Vosloo, R. (eds.), 2011, Living theology: Essays presented to Dirk J. Smit on his sixtieth birthday, Bible Media, Wellington.

Hauerwas, S., 2002, The peacable kingdom: A primer in Christian ethics, University of Notre Dame Press, Notre Dame.

Helberg, J.L., 1980, Die Here regeer: Openbaringslyn deur die Ou Testament, NG Kerkboekhandel, Pretoria.

Hellwig, M.K., 1991, 'Eschatology' in F.S. Fiorenza \& J.P. Galvin (eds.), Systematic Theology, Roman Catholic perspectives, vol. 2, pp. 352-371, Fortress, Minneapolis

Heppe, H., 1978, Reformed dogmatics: Set out and illustrated from the sources, transl. G.T. Thomson, Baker, Grand Rapids.

Heyns, J.A., 1967, Die kerk as diens aan die koninkryk, Universiteit Stellenbosch, Stellenbosch.

Heyns, J.A., 1978, Dogmatiek, NG Kerkboekhandel, Pretoria.

Heyns, J.A., 1992, Inleiding tot die dogmatiek - aan die hand van die Nederlandse Geloofsbelydenis, NG Kerkboekhandel, Halfway House.

Heyns, J.A., 1994b, 'Die betekenis van H.G. Stoker se filosofie vir die teologie', Koers 59(3\&4), 455-471.

Jonker, W.D., 1994, Bevrydende waarheid: Die karakter van die gereformeerde belydenis, Hugenote-Uitgewers, Wellington.

Joubert, S., 2012, Ontsluit die Nuwe Testament: Omvattende Bybelreise vir ' $n$ beter verstaan van die Skrif, Christelike Uitgewersmaatskappy, Vereeniging.

Klein, G., 1970, “'Reich Gottes” als biblischer Zentralbegriff', Evangelische Theologie 50, 642-670.

König, A., 1970, Jesus Christus die Eschatos: Die fundering en struktuur van die eskatologie as teleologiese Christologie, NG Kerkboekhandel, Pretoria.

König, A., 1988, 'Koninkryksteologie of verbondsteologie?', Hervormde Teologiese Studies 44(2), 355-364. http://dx.doi.org/10.4102/hts.v44i2.2214

König, A., 2001, Fokus op die 300 geloofsvrae wat mense die meeste vra: ' $n$ Verwysingsgids vir elke huis, Lux Verbi.BM, Wellington.

König, A., 2014, Die groot geloofsommentaar, Christelike Uitgewersmaatskappy, Vereeniging.

Küng, H., 1967, De kerk, Paul Brand, Hilversum.

Ladd, 1974, The presence of the future: The eschatology of biblical realism, Eerdmans, Grand Rapids.
Merklein, H., 1981, Die Gottesherrschaft als Handlungsprinzip: Untersuchung zur Ethik Jesu, Echter Verlag, Würzburg.

Michealis, J.R., 1987, 'The kingdom of God and the historical Jesus', in W. Willis (ed.), The kingdom of God in 20th-century interpretation, pp. 109-118, Hendrickson, Peabody.

Migliore, D.L., 1991, Faith seeking understanding: An introduction to Christian theology, Eerdmans, Grand Rapids.

Moltmann, J., 1969, Theologie van de hoop: Studies over de grondslagen en konsekwenties van een christelijke eschatologie, vert. J. Van de Geijn, Ambo, Utrecht.

Moltmann, J., 1975, Kirche in der Kraft des Geistes, Kaiser, München.

Moltmann, J., 1980, Trinität und Reich Gottes: Zur Gotteslehre, Kaiser, München.

Moltmann, J., 1996, The coming of God: Christian eschatology, SCM, London.

Moltmann, J., 1997, 'Was heisst heute "evangelisch"? Von der Rechtfertigungslehre zur Reich-Gottes-Theologie', Evangelische Theologie 57(1), 41-46.

Moltmann, J., 2000, Experiences in theology: Ways and forms of Christian' theology, SCM, London.

Moltmann, J., 2012, Ethics of Hope, SCM, London.

Neill, S., 1968, De interpretatie van het Nieuwe Testament, Aula, Utrecht.

Nel, G.C.J. \& Van Aarde, A.G., 2002, 'Die koninkryk van God by Jesus: 'n Apokaliptieseskatologiese of eties-eskatologiese begrip?', HTS Teologiese Studies 58(3), 11131133. http://dx.doi.org/10.4102/hts.v58i3.597

Neuner, J. \& Dupuis, J. (eds.), 1983, The Christian faith in the doctrinal documents of the Catholic Church, Collins, London.

Ngara, E., 2001, The kingdom of God and the Christian life: Towards a new ethos for the followers of Jesus, Unisa, Pretoria.

Niebuhr, H.R., 1956, The kingdom of God in America, Shoestring, Hamden.

Noordmans, O., 1979, Verzamelde Werken, deel 2, Kok, Kampen.

Noordmans, O., 1980, Verzamelde Werken, deel 8, Kok, Kampen

Noordmans, O., 1986, Verzamelde Werken, deel 6, Kok, Kampen.

Olivier, H., 1997, 'Skuldbelydenis en versoening - 'n Ou-Testamentiese perspektief', Nederduitse Gereformeerde Teologiese Tydskrif 38(1\&2), 103-114.

Origenes, 2009, De basis: Onderzoek naar de fundamenten van geloof en wereld, vert. F.J.H Berghuis, Damon, Budel.

Ott, L., 1981, Grundriss der katoloschen Dogmatik, Herder, Freiburg.

Palmer, D.S.k., 1986, The kingdom of God, Evangelical Press, Welwyn.

Pannenberg, W., 1991, Systematic Theology, vol. 2, transl. G.W. Bromiley, Eerdmans, Grand Rapids.

Pannenberg, W., 1993, Systematic Theology, vol. 3, transl. G.W. Bromiley, Eerdmans, Grand Rapids.

Phillips, A.P., 2002, 'Die invloed van die eskatologie op die dogmatiek en etiek van die twintigste eeu', Tydskrif vir Geesteswetenskappe 42(1), 44-53.

Pienaar, A., 2014, God se oë is blou: 'n Kop-en-hart-reis, Naledi, Tygervallei.

Polman, A.D.R., s.a., Onze Nederlandsche Geloofsbelijdenis: Verklaard uit het verleden geconfronteerd met het heden, deel 4, Wever, Franeker.

Preston, R.H., 1993, 'Kingdom of God: Political and social theology', in A.E. McGrath (ed.), The Blackwell Encyclopedia of Modern Christian Thought, pp. 304-309, Blackwell, Oxford.

Ridderbos, H.N., 1950, De komst van het koninkrijk: Jezus' prediking volgens de synoptische evangeliën, Kok, Kampen.

Ridderbos, H.N, 1968, Het Woord, het rijk en onze verlegenheid, Kok, Kampen.

Runia, K., 1997, 'Eschatology in the second half of the twentieth century', Calvin Theological Journal 32(1), 105-135.

Ruppert, M., 1987, Het rijk Gods en de wereld: Over de verhouding tussen het rijk Gods en de wereld naar aanleiding van Luthers onderscheiding van het eeuwige rijk Gods en Gods tijdelike wereldlijke regiment, Kok, Kampen.

Sauter, G., 1999, What dare we hope for? Reconsidering eschatology, Trinity Press International, Harrisburg.

Schleiermacher, F., [1830] 1976, The Christian faith, transI. H.R. Mackintosh \& J.S. Stewart, Clark, Edinburgh.

Schlink, E., 1985, Oekumenische Dogmatik: Grundzüge, Vandenhoeck \& Ruprecht, Göttingen.

Schmidt, K.L., 1965, Basileús, in G. Kittel (ed.), Theological Dictionary of the New Testament, part 1, pp. 576-593, Eerdmans, Grand Rapids.

Schwarz, H., 2000, Eschatology, Eerdmans, Grand Rapids.

Seeberg, R., 1964, Text-book of the history of doctrines, vol. 1 \& 2, transl. C.E. Hay, Baker Book House, Grand Rapids.

Smit, D.J., 2007, Essays in public theology: Collected essays, ed. E.M. Conradie, Sun Press, Stellenbosch.

Snyman, W.J., 1977, Nuwe en ou dinge: Uit die skat van die koninkryk, Pro Rege, Potchefstroom.

Spykman, G.J., 1992, Reformational theology: A new paradigm for doing dogmatics, Eerdmans, Grand Rapids.

Theron, P.F., 1978, Die ekklesia as kosmies-eskatologiese teken - Die eenheid van die kerk as 'profesie' van die eskatologiese vrede, NG Kerkboekhandel, Pretoria. 
Thomas Aquinas, 1989, Summa Theologiae: A concise translation, T. McDermott (ed.), Eyre \& Spottiswoode, London.

Tillich, P., 1968, Systematic theology, vol. 1-3, Nisbet, Digswell Place.

Van Bruggen, W., 1983, Futurum en eschaton: Over de verhouding van het handelen van God en van de mens in de geschiedenis met het oog op de toekomst Callenbach, Nijkerk.

Van de Beek, A., 1996, Schepping: De wereld als voorspel voor de eeuwigheid, Callenbach, Baarn

Van de Beek, A., 2001, Ontmaskering: Christelijk geloof en cultuur, Meinema, Zoetermeer.

Van de Beek, A., 2005, Hierbeneden is het niet: Christelijke toekomstverwachting, Meinema, Zoetermeer.

Van de Beek, A., 2012, Lichaam en Geest van Christus: De theologie van de kerk en de Heilige Geest, Meinema, Zoetermeer.

Van den Brink, G. \& Van der Kooi, C., 2013, Christelijke dogmatiek: Een inleiding, Boekencentrum, Zoetermeer.

Van der Kooi, C., 1992, 'De spanning van het "reeds" en "nog niet" bij Calvijn, Kuyper en Berkouwer' in M.E. Brinkman (red.), 100 jaar Theologie: Aspecten van een eeuw theologie in de Gereformeerde Kerken in Nederland (1892-1992), bl. eeuw theologie in de
248-282, Kok, Kampen.

Van der Kooi, C., 2012, 'Striking similarities: The eschatological orientation of Calvin, Barth and Van de Beek' in E. Van der Borght \& P. Van Geest (eds.), Strangers and pilgrims: Essays in honour of Abraham van de Beek, pp. 371-379, Brill, Leiden.

Van der Walt, T. 1962, Die koninkryk van God - naby! Eksegetiese verkennings van die toekomsperspektief van Jesus Christus volgens die getuienis van die sinoptiese evangelies, Kok, Kampen.

Van der Walt, S.J., 1969, 'Teologies-historiese blik op die gedagte van die koninkryk van God', in S. du Toit et al. (reds.), Die koninkryk van God, bl. 151-184, Potchefstroom Herald, Potchefstroom.

Van der Watt, J. \& Tolmie, F. (reds.), 2014, Ontdek die boodskap van die Nuwe Testament: God se Woord vir vandag, Christelike Uitgewersmaatskappy, Vereeniging.

Van Genderen J. \& Velema, W.H., 1992, Beknopte gereformeerde dogmatiek, Kok, Kampen.

Van Oosterzee, J.J., 1876, Christelijke dogmatiek: Een handboek voor academisch onderwijs en eigen oefening, Deel 1 \& 2, Kemink, Utrecht.

Van Ruler, A.A., 1947, De vervulling van de wet: Een dogmatische studie over de verhouding van openbaring en existentie, Callenbach, Nijkerk.

Van Ruler, A.A., 1971, Theologisch werk, Deel 2, Callenbach, Nijkerk.

Van Ruler, A.A., 1978, Verwachting en voltooiing: Een bundel theologische opstellen en voordrachten, Callenbach, Nijkerk.
Van Wyk, D.J.C. (red.), 1999, 20ste eeu Hervormde teologie, Sentik, Pretoria.

Van Wyk, J.H., 1991, Moraliteit en verantwoordelikheid: Opstelle oor politieke etiek, $\mathrm{PU}$ vir $\mathrm{CHO}$, Potchefstroom.

Van Wyk, J.H., 2001a, 'John Calvin on the kingdom of God and eschatology', In die Skriflig 35(2), 191-205.

Van Wyk, J.H., 2001b, Etiek en eksistensie - In koninkryksperspektief, Potchefstroomse Teologiese Publikasies (PTP), Potchefstroom.

Van Wyk, J.H., 2003a, 'Die Schwarze Theologie von Allan Boesak - Mit besonderem Hinwies auf seine Anthropologie', HTS Teologiese Studies 59(2), 385-401. http://dx.doi.org/10.4102/hts.v59i2.660

Van Wyk, J.H., 2003b, 'Teologie van die verbond of teologie van die koninkryk? Dogmatiese nadenke oor die verhouding tussen die verbond en die koninkryk as sentrale teologiese temas', In die Skriflig, 37(1), 1-26.

Van Wyk., J.H., 2010, “'Is Christ divided?” An analysis of the theological justification of a church schism' in E. Van der Borght (ed.), The unity of the church: A theological state of the art and beyond, pp. 51-67, Brill, Leiden.

Van Wyk, J.H., 2012, 'Die kerk se taak en houding in die eindtyd', in S. Joubert (red.)et al., Is dit die einde van die wêreld?, bl. 49-65, Carpe Diem Media, Vanderbijlpark.

Vaticaan Oecumenisch Concilie, 1967, Constituties en decreten van het 2e Vaticaans Oecumenisch Concilie, Katholiek Argief, Amersfoort.

Von Harnack, A., 1903, Het wezen des Christendoms, vert. C.S.M. Kuenen, Kapteijn, Leiden.

Von Rad, G., 1965, Basileús, in G. Kittel (ed.), Theological Dictionary of the New Testament I, pp. 565-571, Eerdmans, Grand Rapids.

Weber, O., 1972, Grundlagen der Dogmatik II, Neukirchener Verlag, Neukirchen-Vluyn.

Welker, M., 1992, 'Das Reich Gottes', Evangelische Theologie 52, 497-512. http://dx.doi.org/10.14315/evth-1992-0603

Wentsel, B., 1991, God en mens verzoend: Incarnatie, verzoening, koninkrijk van God: Dogmatiek, deel 3b, Kok, Kampen.

Wentsel, B., 2006, Hij-is-er-bij. Handboek Bijbelse Geloofsleer, deel 2, Kok, Kampen.

Williams, S., 1997, 'Thirty years of hope: A generation of writing on eschatology', in K.E. Brower \& M.W. Elliot (eds.), Eschatology in Bible and theology: Evangelical essays at the dawn of a new millennium, pp. 243-262, InterVarsity Press, Downers Grove.

Willis, W., 1987b, 'The discovery of the eschatological kingdom: Johannes Weiss and Albert Schweitzer' in W Willis (ed.), The kingdom of God in 20th-century interpretation, pp. 1-14, Hendrickson, Peabody.

Wolters, A.M., 1992, Die skepping herwin: Bybelse grondslae vir 'n Reformatoriese lewensbeskouing, PU vir CHO/IRS, Potchefstroom.

Zahrnt, H., 1967, Wachtend op God: De Duitse protestantse theologie in de twintigste eeuw, vert. A.M.J. Kreykamp, Ambo, Utecht. 